\title{
CARBON AND NITROGEN STOCKS OF AN ARENOSOL UNDER IRRIGATED FRUIT ORCHARDS IN SEMIARID BRAZIL
} \author{
Emoke Madari²; Sílvio Roberto de Lucena Tavares ${ }^{3}$; David Vilas Boas de Campos ${ }^{3}$; Lindbergue \\ de Araújo Crisóstomo ${ }^{4}$ \\ ${ }^{1}$ Embrapa Pecuária Sudeste, C.P. 339 - 13560-970 - São Carlos, SP - Brasil.
${ }_{2}^{2}$ Embrapa Arroz e Feijão, C.P. 179 - 75375-000 - Santo Antônio de Goiás, GO - Brasil.
${ }_{3}^{3}$ Embrapa Solos, R. Jardim Botânico, 1024 - 22460-000 - Rio de Janeiro, RJ - Brasil.
${ }^{4}$ Embrapa Agroindústria Tropical, C.P. 3761 - 60511-110 - Fortaleza, CE - Brasil.
${ }^{*}$ Corresponding author <alberto@cppse.embrapa.br>
}

Alberto Carlos de Campos Bernardi ${ }^{1 *}$; Pedro Luiz Oliveira de Almeida Machado²; Beata

ABSTRACT: Soil organic matter accumulation provides benefits to soil productivity and reduces atmospheric carbon concentration. However, little is known about the accumulation of $\mathrm{C}$ and $\mathrm{N}$ by sandy soils under perennial irrigated crops in semiarid regions. The objective of this study was to evaluate the effect of irrigated fruit orchard cultivation on the stocks of soil organic carbon (SOC) and total nitrogen $(\mathrm{N})$ of an Arenosol/Quartzpsament from Paraipaba-CE, Semiarid Brazil. Soil samples were taken from irrigated orchards of banana (Musa ssp.), cashew (Anacardium ocidentale), guava (Psidium guajava), bullock's heart (Annona reticulata), mango (Mangifera indica), and sapote (Manilkara zapota) in the wetted-bulb and non-irrigated area between the plant rows. Additional samples were collected from adjacent areas under secondary Caatinga forest, and under a 2-year-old deforested area. Sampling depths were: 0-0.1, 0.1-0.2, and 0.2-0.4 m. The highest contents of SOC and $\mathrm{N}$ were found in the surface layer. The soil bulk density did not change in depth. The stocks of SOC and total $\mathrm{N}$ under secondary forest at $0-0.40 \mathrm{~m}$ layer were 27.6 and $2.4 \mathrm{Mg} \mathrm{ha}^{-1}$, respectively. Caatinga Forest conversion into fruit orchard cultivation led to a decrease of 5 to $23 \%$ and 4 to $21 \%$ on SOC and N stocks, respectively. Compared to other soil uses, sapote and bullock's heart contributed for a lower decrease of SOC and N stocks after deforestation. Guava, bullock's heart, mango and sapote contributed for improving the SOC stratification index.

Key words: Caatinga forest, soil organic matter, soil stratification index

\section{ESTOQUES DE CARBONO E NITROGÊNIO DE UM NEOSSOLO QUARTZARÊNICO SOB CULTIVO DE FRUTEIRAS IRRIGADAS NA REGIÃO DO SEMI-ÁRIDO DO BRASIL}

\begin{abstract}
RESUMO: O acúmulo de matéria orgânica beneficia a produtividade do solo e reduz a concentração do carbono atmosférico. Entretanto, pouco é sabido a respeito do acúmulo de $\mathrm{C}$ e $\mathrm{N}$ em solos arenosos cultivados com culturas perenes irrigadas em regiões semi-áridas. O objetivo deste trabalho foi avaliar o efeito do cultivo de fruteiras irrigadas nos estoques de $\mathrm{C}$ e $\mathrm{N}$ de um Neossolo Quartzarênico em Paraipaba, CE. Foram coletadas amostras na linha e na entrelinha de pomares irrigados de banana, caju, manga, sapoti, goiaba e graviola. Em áreas adjacentes sob vegetação de Caatinga hipoxerófila e após dois anos de desmatamento foram coletadas amostras adicionais. As profundidades de amostragem foram: 0 a $0.1,0.1$ a 0.2 e 0.2 a $0.4 \mathrm{~m}$. Os teores de $\mathrm{C}$ e $\mathrm{N}$ no solo foram mais altos na camada superficial $(0$ a $0.1 \mathrm{~m})$. Não houve efeito da profundidade de amostragem sobre a densidade do solo. Os estoques de $\mathrm{C}$ e $\mathrm{N}$ na área com vegetação de Caatinga na camada de 0 a 0.4 $\mathrm{m}$ foram de 27,6 and 2,4 $\mathrm{Mg} \mathrm{ha}^{-1}$, respectivamente. A retirada da vegetação natural e o cultivo das fruteiras levaram a reduções de 5 a $23 \%$ e 4 a $21 \%$ nos estoques de $\mathrm{C}$ e $\mathrm{N}$ do solo, respectivamente. As culturas do sapoti e da graviola contribuíram para o aumento dos estoques de $\mathrm{C}$ e $\mathrm{N}$ após a retirada da vegetação natural. As culturas da goiaba, graviola, manga e sapoti contribuíram para a melhoria do índice de estratificação deste solo.

Palavras-chave: Caatinga, matéria orgânica do solo, índice de estratificação do solo
\end{abstract}




\section{INTRODUCTION}

Soil organic matter (SOM) has many functions and the relative importance of each differs with soil type, climate and land use. Commonly the most important function of the organic matter (OM) in soils is as a reserve of $\mathrm{N}$ and other nutrients required by plants. Other important functions include the formation of stable aggregates and soil surface protection, maintenance of vast array of biological functions, including the immobilization and release of nutrients, provision of ion exchange capacity, and storage of terrestrial C (Craswell \& Lefroy, 2001; Robert, 2001).

Carbon is added to the soil by green plants that capture $\mathrm{CO}_{2}$ from the atmosphere by photosynthesis to form $\mathrm{C}$-compounds. The plant $\mathrm{C}$ enters to the SOM pool as plant litter, root material and exudates or, if consumed by animals, as excreta. These processes occur mostly near the soil surface and, therefore, the $\mathrm{C}$ that is accumulating is easily lost as a result of soil erosion or increased tillage intensity. Some of the $\mathrm{C}$ and essential elements in these fractions become nutrients for the soil flora and fauna (Follet, 2001; Robert, 2001).

Since surface OM is essential for erosion control, water infiltration, and conservation of nutrients, Franzluebbers (2002) proposed that the degree of stratification of soil organic $\mathrm{C}$ pools with soil depth, expressed as ratios, could indicate soil quality or soil ecosystem functioning. According to this author, stratification ratios allow a wide diversity of soils to be compared on the same assessment scale because of an internal normalization procedure that accounts for inherent soil differences, and values lower than 2 indicate soil degradation.

Soil $\mathrm{C}$ accumulation provides benefits to soil productivity and reduces atmospheric $\mathrm{C}$ concentration. The gain in soil productivity is a slow process and attaining a steady state level of $\mathrm{C}$ in soil takes several years. Most agricultural practices will not cause soil $\mathrm{C}$ accrual to rates in a short period, it takes at least 25-50 years before a new organic $C$ steady state is reached in soils (Batjes, 2001). However, the time scale and feedback mechanisms of changes in soil organic carbon (SOC) as well as the steady state level for specific soil types, climates and land use are not well known despite their relevance for predicting future soil quality and degradation, long-term productivity and the potential release of greenhouse gasses.

Most reports on $\mathrm{C}$ and $\mathrm{N}$ stocks in Brazilian agricultural soils are based on grain crop systems of regions under high rainfall (Freixo et al., 2002; Machado \& Silva, 2001; Sisti et al., 2004). Tiessen et al. (1998) attempted to estimate the total soil storage of an Oxisol under natural vegetation in the Brazilian semiarid region, obtaining values near $20 \mathrm{Mg} \mathrm{ha}^{-1}$ for the surface layer. An Alfisol in the same region contained approximatelly $28 \mathrm{Mg} \mathrm{ha}^{-1}$, between 0 to $0.2 \mathrm{~m}$ (Kauffman et al., 1993). However, little is known about the accumulation of $\mathrm{C}$ by sandy soils under perennial irrigated crops in semiarid regions. Cultivation of fruit orchards in irrigated areas is being considered a profitable alternative to the slash and burn system for farmers in these dry areas. Research data on soil C stocks under irrigation is scarce and more information is still needed. Water application is important for increasing biomass yields, and Lal et al. (1998) estimated that irrigation results in a soil $\mathrm{C}$ sequestration rate between 50 and $150 \mathrm{~kg} \mathrm{ha}^{-1} \mathrm{yr}^{-1}$.

Improved agricultural practices have great potential to increase the amount of $\mathrm{C}$ sequestered in cropland soils. Changes in land cover associated with different land uses are important agents of environmental change and degradation in the semiarid tropics. The objective of this work was to evaluate the effect of irrigated fruit orchard growth on SOC and total N stocks of an Arenosol from Paraipaba-CE, Brazil.

\section{MATERIAL AND METHODS}

The study area is located in Paraipaba ( $3^{\circ} 28^{\prime} 52^{\prime \prime} \mathrm{S}$ and $39^{\circ} 09^{\prime} 52^{\prime \prime} \mathrm{W} ; 30 \mathrm{~m}$ above sea level), State of Ceará, Brazil. The climate of the region is Bw (Köeppen's classification) with a yearly average temperature of $26.7^{\circ} \mathrm{C}$, relative humidity of $71 \%$, and total precipitation of $998 \mathrm{~mm}$. The soil type is an Arenosol, with $892 \mathrm{~g} \mathrm{~kg}^{-1}$ of sand; $32 \mathrm{~g} \mathrm{~kg}^{-1}$ of silt, and $76 \mathrm{~g} \mathrm{~kg}^{-1}$ of clay at $0-0.27 \mathrm{~m}$ (A horizon). In the $0.27-0.76 \mathrm{~m}$ layer it contains $820 \mathrm{~g} \mathrm{~kg}^{-1}$ of sand; $53 \mathrm{~g} \mathrm{~kg}^{-1}$ of silt, and $126 \mathrm{~g} \mathrm{~kg}^{-1}$ of clay.

Soil samples were taken from orchards of banana (Musa ssp.), cashew (Anacardium ocidentale), guava (Psidium guajava), bullock's heart (Annona reticulata), mango (Mangifera indica), and sapote (Manilkara zapota) in the irrigated wet bulb in the plant row and in the non-irrigated area between plant rows. Apart from banana, which has been cultivated for two years, all crops were six years old. Additional soil samples were collected from an adjacent area under secondary dry forest classified as "Caatinga Hipoxerófila" (Brasil, 1973), under a 2-year-old deforested and a recently ploughed area. All sampled areas belong to the same soil type.

Fruit-tree spacing and orchard area were as follows: Cashew, mango and sapote, $5.0 \mathrm{~m} \times 3.0 \mathrm{~m}$ (667 plant ha ${ }^{-1}$ ), each orchard covering 1.6 ha; guava and bullock's heart, $3.0 \mathrm{~m} \times 3.0 \mathrm{~m}\left(1,111\right.$ plant ha $\left.^{-1}\right)$, each orchard covering $1.0 \mathrm{ha}$; and banana, $4.0 \mathrm{~m} \times$ 
$2.0 \mathrm{~m}\left(1,250\right.$ plant ha $\left.^{-1}\right)$ covering 0.5 ha. All orchards were supplied with $1.000 \mathrm{~kg} \mathrm{ha}^{-1}$ of dolomite limestone at planting. Table 1 shows the fertilizer levels added to the fruit orchards from planting to sampling time. All fruit trees were microsprinkler irrigated, powered by a hydroelectric pump. The flow rate and wetted area were $20 \mathrm{~L} \mathrm{~h}^{-1}$ and $1.0 \mathrm{~m}^{2}$ in diameter for all fruits, and $28 \mathrm{~L} \mathrm{~h}^{-1}$ and $1.5 \mathrm{~m}^{2}$ only for banana.

Samples were taken from pits (triplicate) dug to $0.70 \mathrm{~m}$ depth and with $1 \mathrm{~m}^{2}$ area in which approximately $0.3 \mathrm{~kg}$ of soil material was collected from each depth. Sampling depths were 0-0.1, 0.1-0.2, and 0.2$0.4 \mathrm{~m}$, as recommended by Houghton et al. (1997) for soil $\mathrm{C}$ inventories. Soil samples were air dried and passed through a 2-mm sieve. Organic C (SOC) and total $\mathrm{N}(\mathrm{N})$ contents were determined by wet combustion (Walkey-Black method) and semi-micro-Kjeldahl digestion, respectively (EMBRAPA, 1997).

Soil bulk density was measured for each depth by the core method (EMBRAPA, 1997) using $5 \times 5$ $\mathrm{cm}$ stainless steel rings. Carbon and $\mathrm{N}$ stocks were computed until the $0.4 \mathrm{~m}$ depth on a unit area basis for all depths, and the correction of soil compaction was made following Sisti et al. (2004). Where contrasting management can lead to changes in bulk density, the desirability of adjusting sampling depths, or mathematically correcting results so that an equivalent soil mass is considered, has been emphasized in a previous comparison of soil management systems (Powlson \& Jenkinson, 1981; Smith et al., 1998). To correct for the compaction of the soil induced by cultivation and traction of agricultural machinery, the SOC and $\mathrm{N}$ stocks in the soil were estimated as the SOC or $\mathrm{N}$ content of the same weight of soil as that present to $0.4 \mathrm{~m}$ depth in the adjacent Caatinga forest (mean of three profiles), following Vallis (1972). It was assumed that soil compaction due to mechanical operations was most significant in the surface layers of the

Table 1 - Fertilizer levels added to fruit orchards.

\begin{tabular}{lllll}
\hline \multirow{2}{*}{ Fruit orchard } & \multicolumn{4}{c}{ Fertilizer* } \\
\cline { 2 - 5 } & $\mathrm{N}$ & $\mathrm{P}_{2} \mathrm{O}_{5}$ & $\mathrm{~K}_{2} \mathrm{O}$ & FTE-BR 12 \\
\hline Banana & 0.44 & 0.18 & 0.44 & 0.05 \\
Bullock's heart & 1.6 & 1.0 & 1.07 & 0.25 \\
Caschew & 1.20 & 0.6 & 1.05 & 0.2 \\
Guava & 1.6 & 0.7 & 1.07 & 0.25 \\
Mango & 1.24 & 1.2 & 1.16 & 0.15 \\
Sapote & 1.24 & 1.2 & 1.16 & 0.15
\end{tabular}

*In form of urea (N 45\%), simple superphosphate $\left(\mathrm{P}_{2} \mathrm{O}_{5} 18 \%\right)$, potassium chloride $\left(\mathrm{K}_{2} \mathrm{O} 60 \%\right)$, and FTE-BR 12 (B 1.8\%; Cu $0.8 \%$; Fe 3\%; Mn 2\%; Mo 0.1\%; Zn 9\%). profiles so that the SOC and N stocks were calculated by subtracting the SOC and $\mathrm{N}$ contents of the extra weight of soil in the deepest $(0.2-0.4 \mathrm{~m})$ layer sampled of each profile (Neill et al., 1997). This correction can be expressed mathematically as:

$\mathrm{Cs}=\sum_{\mathrm{i}=1}^{\mathrm{n}-1} \mathrm{C}_{\mathrm{Ti}_{\mathrm{i}}}+\left[M_{T_{n}}-\left(\sum_{i=1}^{n} M_{T_{i}}-\sum_{i=1}^{n} M_{S_{i}}\right)\right] C_{T_{n}}$

where $C s$ is the SOC stock $\left(\mathrm{Mg} \mathrm{C} \mathrm{ha}^{-1}\right)$ in soil to a depth equivalent to the same mass of soil as that in the reference profile; $\sum^{n-1} C_{T_{i}}$ the sum of the SOC stock $\left(\mathrm{Mg} \mathrm{ha}^{-1}\right)$ in the layers $1^{1}$ (surface) to layer $n-1$ in the treatment profile, the sum of the mass of soil $\left(\mathrm{Mg} \mathrm{ha}^{-1}\right)$ in layers 1 (surface) to $n$ (greatest depth) in the reference soil profile; $\sum^{n-1} M_{T_{i}}$ the sum of the mass of soil (Mg ha $^{-1}$ ) in layers 1 (surface) to $n$ (greatest depth) in the treatment profile, $M_{T_{n}}$ the mass of soil in the deepest layer in the treatment profile and $C_{T_{n}}$ the SOC content $(\mathrm{Mg} \mathrm{C}$ per $\mathrm{Mg}$ soil) in the deepest layer in the treatment profile.

As suggested by Franzluebbers (2002), the stratification index was also calculated by the difference of SOC contents between the 0-0.1 and the 0.1$0.2 \mathrm{~m}$ layer.

\section{RESULTS AND DISCUSSION}

Generally, there were no differences of SOC and $\mathrm{N}$ contents between samples from wetted-bulb and non-irrigated areas between the plant rows Table 2 . However, soils under banana and mango presented differences especially at the top layer $(0$ to $0.1 \mathrm{~m})$. The amount of SOC present is a function of the rate of SOC decomposition and the quantity and composition of crop residues, plant roots, and other organic material returned to the crop residues and other organic materials (Follet, 2001). The SOC contents in soils reflect the long-term balance between additions and losses of SOC. Following the advent of soil cultivation, this long-term balance was disrupted and more and more of the $\mathrm{C}$ in the soil organic matter was exposed to oxidative processes, as confirmed by the $20 \%$ reduction of SOC contents ( 0 to $0.4 \mathrm{~m}$ depth) in the 2-year-old deforested soil as compared with the soil under secondary forest. Data from Salcedo et al. (1997) showed that after 6 years of manual cultivation, there was a $16 \%$ decline in SOM.

Concentrations of soil organic carbon and $\mathrm{N}$ from wetted-bulb and non-irrigated areas between the plant rows were higher in the surface layer $(0-0.1 \mathrm{~cm})$ than in the deeper soil horizons due to the influence of litter deposition and high root density (Table 2). The contents of SOC in the 0 to 0.1 and 0.1 to $0.2 \mathrm{~m}$ lay- 


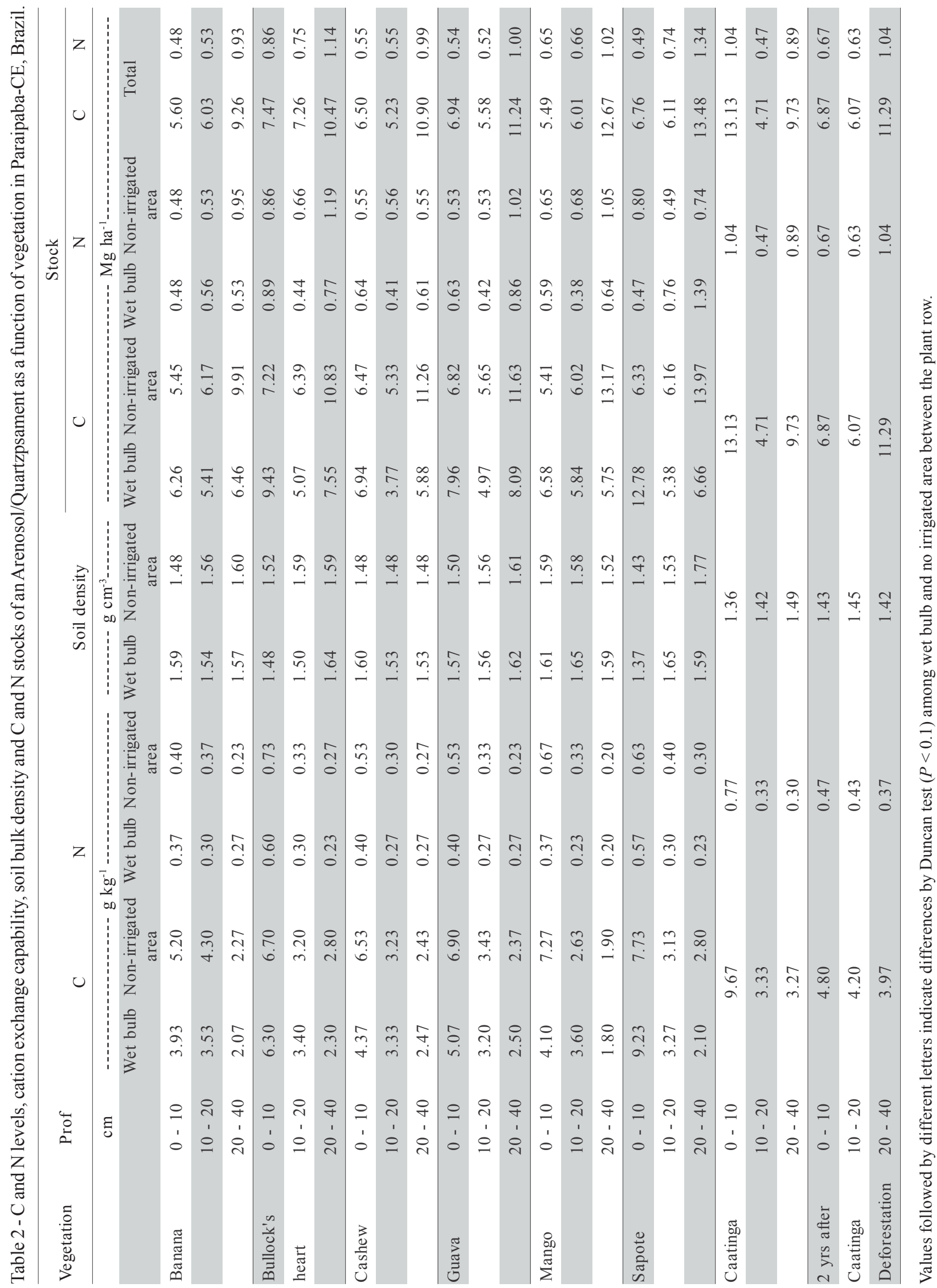


ers were between 3 and $9 \mathrm{~g} \mathrm{~kg}^{-1}$, and are in agreement with values reported by Tiessen et al. (1998). These authors, based on soil survey map information from NE Brazil, pointed out that $\mathrm{C}$ contents ranged between 4 to $11 \mathrm{~g} \mathrm{~kg}^{-1}$ for medium textured soils and from 10 to $20 \mathrm{~g} \mathrm{~kg}^{-1}$ for the heavier textured soils.

The carbon:nitrogen ratios calculated from Table 2 data, were relatively higher in the top layer (C:N $\cong 12)$ than in the deeper soil horizons $(\mathrm{C}: \mathrm{N} \leq 10)$. Alves et al. (1999) found values close to these ratios in a study on twenty soils from the Pernambuco State, NE Brazil. Compared to deeper soil horizons, higher $\mathrm{C}: \mathrm{N}$ ratio in the top layer is due to the influence of above-ground plant residues on soil organic matter characteristics (Diekow et al., 2005). A similar trend of increase of the C:N ratio in depth was also observed by Sá et al. (2001).

Soil bulk density was not affected by the sampling depth in the fruit orchard (Table 2). This is probably due to a homogeneous distribution of sand throughout the profile. Compared to other soils, the soil under secondary forest had lower density at the surface layer ( 0 to $0.1 \mathrm{~m}$ ).

Stocks of SOC and N in the wetted bulb and non-irrigated area between plant rows are shown in Table 2 and they were calculated considering the correction of soil compaction (Vallis, 1972; Neill et al., 1997; Sisti et al., 2004). The SOC and N stocks were estimated in proportion of irrigated and non-irrigated areas as a function of plant stand and wetted perimeter. Thus the calculated irrigated areas were: $18.75 \%$ for banana; $11.11 \%$ for guava and bullock's heart; and $6.67 \%$ for cashew, mango and sapote. The remaining area was considered non-irrigated.

The conversion of forest to agriculture induced changes in the SOC and N stocks (Table 2). Considering the top $0.2 \mathrm{~m}$, the soil under Caatinga forest contained 17.84 Mg SOC ha ${ }^{-1}$ and in the 2-year-old deforested area, the SOC stock decreased near 28\% (12.94 Mg C ha ${ }^{-1}$ ). Compared to the secondary forest soil, soils under guava, banana, cashew, and mango crops had a 30 to $35 \%$ decrease of SOC stock in the 0 to $0.2 \mathrm{~m}$ layer. Soils under bullock's heart and sapote had an apparent improvement on SOC stock, since the $\mathrm{C}$ stocks were 7 and $5 \%$ greater than the 2-year-old deforested area. Nevertheless, a long period is necessary before a new organic $C$ steady state in soils be established Batjes (2001). Thus, further investigations are needed to verify whether the SOC increase under bullock's heart and sapote was an effect of high root growth (Fisher et al., 1994), older SOC (Martinelli et al., 1996; Machado et al., 2003), or both.

Figure 1 illustrates the differences on SOC and $\mathrm{N}$ stocks of soils under secondary forest, 2-year old deforested area and fruit crops in the 0-0.4 m layer. The value of 27.6 Mg SOC ha ${ }^{-1}$ (until 40-cm depth) of Caatinga soil is in agreement with those presented by Kauffman et al. (1993) and Tiessen et al. (1998) for the Northeast Brazilian semiarid region which found 20 to $28 \mathrm{Mg} \mathrm{C}^{-1}$, for surface layers of an Oxisol and an Alfisol, respectively. After six years of fruit orchard cultivation, compared to the soil under secondary forest, SOC stocks decreased 12 to $24 \%$ in soils under mango, guava, cashew, and banana. Sapote and bullock's heart fruit crop had 5 and 9\% decrease of SOC stocks as compared to the secondary forest, notwithstanding 9 and $4 \%$ increase in relation to the 2year deforested area. The stocks of $\mathrm{N}$ decreased 4 to $21 \%$ in soils under mango, cashew, guava and banana. However, N stocks increased 13 and $8 \%$ for soils under bullock's heart and sapote, respectively.

Soil cultivation led to organic matter degradation and caused SOC losses despite annual input by some fruit crops. Results from Tiessen et al. (1994) using radiocarbon confirm the fast turnover, showing that the mean residence time of carbon remaining after $30 \%$ loss was no higher than that of the original uncultivated soil. Nevertheless, there were differences on SOC accumulation depending on the crop. Sapote (M. zapota) was the most efficient crop in $\mathrm{C}$ input to
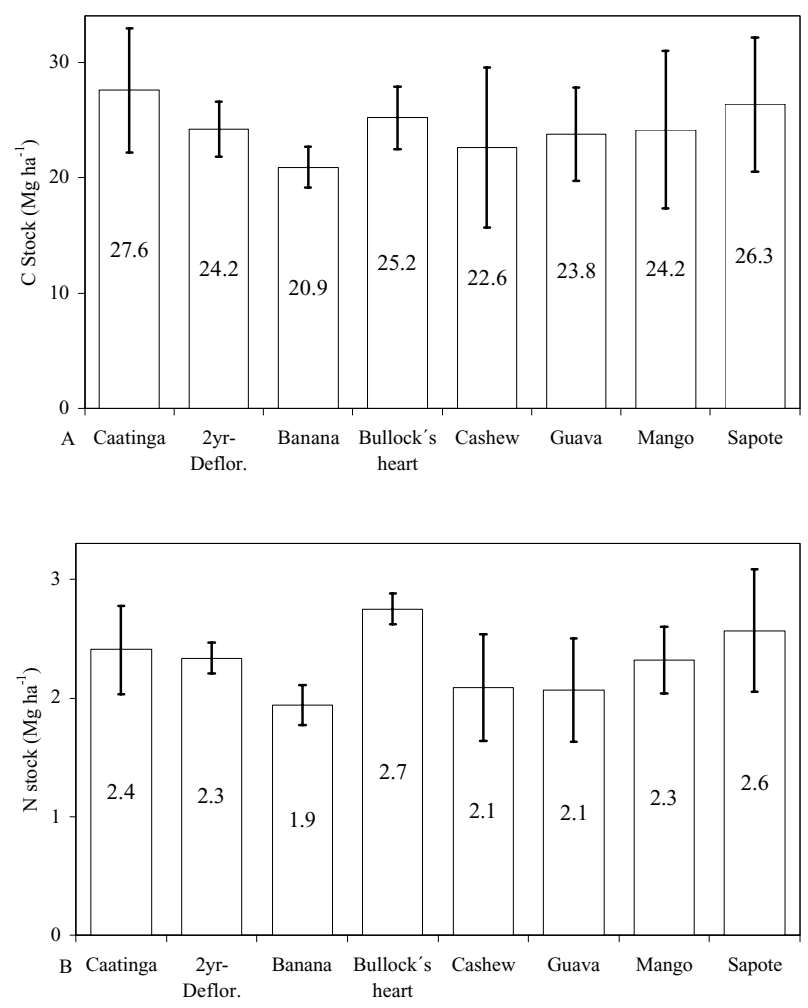

Figure 1 - C (A) and N (B) stocks for the 0-0.4 m layer of an Arenosol/Quartzpsament as a function of vegetation in Paraipaba-CE, Brazil. 
the soil. Bullock's heart (A. reticulata) also presented a potential for improvement in SOC and N stocks. The above-ground crop residues are highly important for enhancing the SOC content, like the $\mathrm{C}$ in the belowground root biomass and the total biomass produced by weeds (Follet, 2001). The author reported that the increase in SOC content by crop residues and roots depends on the quantity and quality of the residue, its management, and soil properties.

Figure 2 presents the ratios between SOC of the surface layer ( 0 to $0.1 \mathrm{~m}$ ) and 0.1 to $0.2 \mathrm{~m}$ on the wet bulb and not irrigated area based on Franzluebbers' (2002) index. Values lower than 2, which indicate decreasing soil quality was observed at the 2-year-old deforested area, and at banana and cashew crop sites (wet bulb and not irrigated area, and sapote not irrigated area). After Caatinga forest conversion into agriculture, the index value decreased $60 \%$, varying from 2.9 to 1.2 after deforestation. Deforestation led to decreased soil quality due to SOC losses in surface layer. Otherwise, the growth of crops like guava, bullock's heart, mango and sapote contributed for improving this index, with values around 2,1 (higher than the quality limit). These values also suggest a slight improvement on soil quality after forest conversion into agriculture. However, these crop indexes are $30 \%$ lower than the
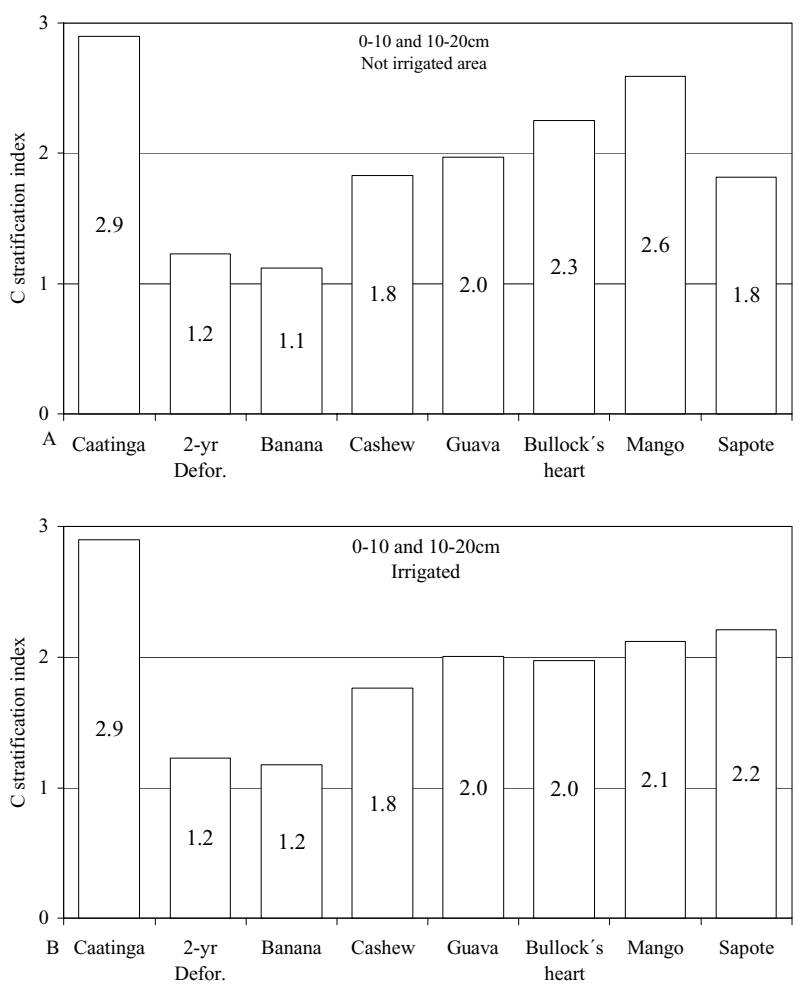

Figure 2 - $\mathrm{C}$ stratification index due to SOC difference from 0-0.1 and 0.1-0.2 m layers at not irrigated areas (A) and wet bulb areas (B) of an Arenosolo/Quartzpsament as a function of vegetation in Paraipaba-CE, Brazil. original index. These data indicated that soil cultivation under irrigation of fruit orchards may contribute to a decrease in SOC losses.

\section{CONCLUSIONS}

The stocks of SOC and $\mathrm{N}$ under secondary forest for the 0-0.4 m layer were 27.6 and $2.4 \mathrm{Mg}$ $\mathrm{ha}^{-1}$, respectively. Forest clearing and fruit orchard cultivation led to decreases of 5 to $23 \%$ and 4 to $21 \%$ on soil $\mathrm{C}$ and $\mathrm{N}$ stocks, respectively. Sapote and bullock's heart crops contributed to improve SOC and $\mathrm{N}$ stocks after deforestation. Guava, bullock's heart, mango and sapote crops contributed for an improvement of the stratification index of this Arenosol.

\section{REFERENCES}

ALVES, G.D.; SAMPAIO, E.V.S.B.; SALCEDO, I.H.; SILVA, V.M. Potencial de mineralização de $\mathrm{N}$ e de $\mathrm{C}$ em vinte solos de Pernambuco. Revista Brasileira de Ciência do Solo, v.23, p.245-256, 1999.

BATJES, N.H. Options for increasing carbon sequestration in West African soils an exploratory study with special focus on Senegal. Land Degradation and Development, v.12, p.131-142, 2001.

BRASIL. Ministério da Agricultura. Divisão de Pesquisa Pedológica. Levantamento exploratório - reconhecimento de solos do Estado do Ceará. Rio de Janeiro: MA-DNPEA; Recife: SUDENEDRN, 1973. 2v. (Boletim Técnico, 28; Série Pedologia, 16).

CRASWELL, E.T.; LEFROY, R.D.B. The role and function of organic matter in tropical soils. Nutrient Cycling and Agroecosystem, v.61, p.7-18, 2001.

DIEKOW, J.; MIELNICZUK, J.; KNICKER, H.; BAYER, C.; DICK, D.P.; KÖGEL-KNABER, I. Soil $\mathrm{C}$ and $\mathrm{N}$ stocks as affected by cropping systems and nitrogen fertilization in a Southern Brazil Acrisol managed under no-tillage for 17 years. Soil and Tillage Research, v.81, p.87-95, 2005.

EMPRESA BRASILEIRA DE PESQUISA AGROPECUARIA. Centro Nacional de Pesquisa de Solos. Manual de métodos de análise de solo. 2.ed. Rio de Janeiro: EMBRAPA, CNPS, 1997. 212p. (Documentos, 1).

FISHER, M.J.; RAO, I.M.; AYARZA, M.A.; LASCANO, C.E.; SANZ, J.I.; THOMAS, R.J.; VERA, R.R. Carbon storage by cultivated deep-rooted grasses in the South American savannahs. Nature, v.371, p.236-238, 1994.

FOLLETT, R.F. Soil management concepts and carbon sequestration in cropland soils. Soil and Tillage Research, v.61, p.77-92, 2001.

FRANZLUEBBERS, A.J. Soil organic matter stratification ratio as an indicator of soil quality. Soil and Tillage Research, v.66, p.95-106, 2002.

FREIXO, A.A.; MACHADO, P.L.O.A.; SANTOS, H.P.; SILVA, C.A.; FADIGAS, F.S. Soil organic carbon and fractions of a Rhodic Ferrasol under the influence of tillage and crop rotation systems in southern Brazil. Soil and Tillage Research, v.64, p. $221-230,2002$.

HOUGHTON, J.T.; MEIRA FILHO, L.G.; LIM, B.; TRÉANTON, K.; MAMATY, I.; BONDUKI, Y.; GRIGGS, D.J.; CALLANDER, B.A. Revised 1996 IPCC Guidelines for National Greenhouse Gas Inventories. Paris: IPCC; UNEP; OECD; IAEA, 1997. 3v.

KAUFFMAN, J.B.; SANFORD JR., R.L.; CUMMINGS, D.L.; SALCEDO, I.H.; SAMPAIO, E.V.S.B. Biomass and nutrient dymnamics associated with slash fires in neotropical dryforests. Ecology, v.74, p.140-151, 1993 
LAL, R.; KimBle, J.M.; FOlletT, R.F.; COLE, C.V. The potential of US cropland to sequester carbon and mitigate the greenhouse effect. Chelsea: Ann Arbor Press, 1998. 128p.

MACHADO, P.L.O.A.; SILVA, C.A. Soil management under notillage systems in the tropics with special reference to Brazil. Nutrient Cycling and Agroecosystem, v.61, p.119-130, 2001.

MACHADO, P.L.O.A.; SOHI, S.P.; GAUNT, J.L. Effect of notillage on turnover of organic matter in a Rhodic Ferralsol. Soil Use and Management, v.19, p.250-256, 2003.

MARTINELLI, L.A.; PESSENDA, L.C.R.; ESPINOZA, E.; CAMARGO, P.B.; TELLES, E.C.; CERRI, C.C.; VICTORIA, R.L.; ARAVENA, R.; RICHEY, J.; TRUMBORE, S. Carbon-13 variation with depths in soils of Brazil and climate change during the Quaternary. Oecologia, v.106, p.376-381, 1996.

NEILl, C.; MELILlO, J.M.; STEUDLER, P.A.; CERRI, C.; MORAES, F.L.; PICCOLO, M.C.; BRITO, M. Soil carbon and nitrogen stocks following forest clearing for pasture in the southwestern Brazilian Amazon. Ecological Applications, v.7, p.1216-1225, 1997.

POWLSON, D.S.; JENKINSON, D.S. A comparison of the organic matter, biomass, adenosine triphosphate and mineralizable nitrogen contents of ploughed and direct-drilled soils. Journal of Agricultural Science, v.97, p.713-721, 1981.

ROBERT, M. Soil carbon sequestration for improved land management. Rome: FAO, 2001. 58p. (World Soil Resources Reports, 96).

SÁ, J.C.M.; CERRI, C.C.; DICK, W.A.; LAL, R.; VENSKE-FILHO, S.P.; PICCOLO, M.C.; FEIGL, B.E. Organic matter dynamics and carbon sequestration rates for a tillage chronosequence in a Brazilian Oxisol. Soil Science Society of America Journal, v.64, p.1486-1499, 2001
SALCEDO, I.H.; TIESSEN, H.; SAMPAIO, E.V.S.B. Nutrient availability in soil samples from shifiting cultivation sites in the semi-arid Caatinga of NE Brazil. Agricultural Ecosystem Environment, v.65, p.177-186, 1997.

SISTI, C.P.J.; SANTOS, H.P.; KOHHANN, R.; ALVES, B.J.R.; URQUIAGA, S.; BODDEY, M.B. Change in carbon and nitrogen stocks in soil under 13 years of conventional or zero tillage in southern Brazil. Soil and Tillage Research, v.76, p.39-58, 2004.

SMITH, P.; POWLSON, D.S.; GLENDINING, M.J.; SMITH, J.U. Preliminary estimates of the potential for carbon mitigation in European soils through no-till farming. Global Change Biology, v.4, p.679-685, 1998.

TIESSEN, H.; CUEVAS, E.; CHACON, P. The role of soil organic matter in sustaining soil fertility. Nature, v.371, p.783-785, 1994.

TIESSEN, H.; FELLER, C.; SAMPAIO, E.V.S.B.; GARIN, P. Carbon sequestration and turnover in semiarid savannas and dry forest. Climate Change, v.40, p.105-117, 1998.

VALLIS, I. Soil nitrogen changes under continuously grazed legumegrass pastures in subtropical coastal Queensland. Australian Journal of Experimental Agriculture and Animal Husbandry, v.12, p.495-501, 1972.

Received December 19, 2005

Accepted March 02, 2007 